\title{
Recent Developments in International Climate Change Law
}

\author{
Pacific Island Countries' Contributions
}

\author{
Sarah Mead \\ Legal Associate at the Climate Litigation Network, Urgenda Foundation, \\ Amsterdam, The Netherlands \\ sarah.leslie.mead@gmail.com \\ Margaretha Wewerinke-Singh \\ Assistant Professor, Grotius Centre for International Legal Studies, Leiden \\ University, Leiden, The Netherlands \\ Adjunct Senior Lecturer, Pacific Centre for Environment and Sustainable \\ Development, University of the South Pacific, Suva, Fiji \\ m.j.wewerinke@law.leidenuniv.nl
}

\begin{abstract}
This article discusses recent developments in international climate change law, in respect of which Pacific island countries and territories (PICs) have made a particularly significant contribution. PICs have been instrumental in shaping the international climate change treaty regime since its inception in the early 199os. Since the adoption of the Paris Agreement in 2015, however, progress has stalled - and even more so since the global pandemic. With a focus on the Suva Declaration on Climate Change released prior to negotiations in Paris, this article assesses progress in two areas that have received considerable attention from PIC representatives due to their importance to the region: the long-term temperature goal and the Talanoa Dialogue; and the issue of loss and damage. While PICs have managed to make gains in both areas, climate change science indicates that current global efforts are insufficient to avoid catastrophic climate change impacts for the Pacific region. In light of this, certain PIC leaders are looking outside of the international treaty system for other ways to protect their communities and ecosystems.
\end{abstract}




\section{Keywords}

Pacific Islands - climate change - international law - Paris Agreement - Suva Declaration on Climate Change - Talanoa Dialogue - mitigation - loss and damage

\section{Introduction}

This article discusses recent developments in international climate change law, in respect of which Pacific island countries and territories (PICs) have made a particularly significant contribution. It focuses on mitigation and loss and damage - two areas that have received considerable attention from PIC representatives in negotiations given their importance to the region. The Paris Agreement, ${ }^{1}$ adopted in 2015 , was hailed by then Secretary-General Ban Ki-moon as a 'monumental triumph'2 and by the media as the 'world's greatest diplomatic success'. ${ }^{3}$ PICs played a key role in shaping the Paris Agreement. Since Paris, however, progress has stalled. Despite the inclusion of the $1.5^{\circ} \mathrm{C}$ long-term temperature goal in the Agreement, current commitments under the Paris Agreement are expected to lead to about $3^{\circ} \mathrm{C}$ of global warming. 4 Similarly, the inclusion of a dedicated article on loss and damage has yet to lead to any real progress in terms of action and support. In light of this, PIC leaders are unsurprisingly looking outside the international climate change treaty regime ('climate treaty regime') for alternative means to prevent catastrophic climate change impacts in the region. Speaking at the Climate Vulnerable Forum in November 2018, the Foreign Minister of Vanuatu, Ralph Regenvanu, announced Vanuatu's intention to explore 'all avenues to utilise the judicial system in various jurisdictions - including under international law - to shift the costs of climate protection back onto the fossil fuel companies, the

1 Decision 1/CP.21, Adoption of the Paris Agreement 2015, UN Doc FCCC/CP/2015/10/Add 1 (29 January 2016) (Paris Agreement).

2 'COP21: UN chief hails new climate change agreement as "monumental triumph", UN News Centre (12 December 2015) <http://www.un.org/apps/news/story.asp?NewsID=52802\#.Vrh4

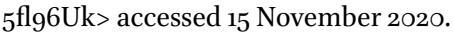

3 Fiona Harvey, 'Paris Climate Change Agreement: The World's Greatest Diplomatic Success' The Guardian (14 December 2014) <https://www.theguardian.com/environment/2015/dec/13/ paris-climate-deal-cop-diplomacy-developing-united-nations $>$ accessed 15 November 2020.

4 UN Environment Programme, 'Emissions Gap Report 2019' (2019) p. XIX. 
financial institutions and the governments that actively and knowingly created this existential threat to [his] country. ${ }^{5}$

\section{From Suva to Paris}

The Suva Declaration on Climate Change arose out of the Pacific Islands Development Forum's (PIDF) Third Annual Summit held in Suva, Fiji, in September $2015 .{ }^{6}$ The Declaration can be seen in the context of a 'paradigm shift' in regional diplomacy towards a heightened Pacific voice in global affairs. ${ }^{7}$ Released prior to the 21st Conference of the Parties (COP) - during which the Paris Agreement was adopted - PIC leaders set out their key demands for the upcoming negotiations.

First and foremost, the Suva Declaration sought inclusion in the Paris Agreement of a long-term temperature goal of $1.5^{\circ} \mathrm{C}$ above pre-industrial temperatures. Prior to the Paris negotiations, the Report from the Structured Expert Dialogue highlighted that $2^{\circ} \mathrm{C}$ of global warming entailed significant risks for vulnerable communities and systems. ${ }^{8}$ The Declaration thus noted that the "the $2^{\circ} \mathrm{C}$ "guardrail" concept is no longer safe for the survival of our Pacific Small Island Developing States', and that states' Intended Nationally Determined Contributions (INDC) were 'grossly inadequate' to keep global temperature increase to below $1.5^{\circ} \mathrm{C}^{9}$ The Declaration thus urged all states to cooperate with a view to 'accelerating the reduction of global greenhouse gas emissions on the basis of equity and in accordance with their common but

5 Lisa Cox, 'Vanuatu Says It May Sue Fossil Fuel Companies and Other Countries over Climate Change' The Guardian (22 November 2018) <https://www.theguardian.com/world/2018/ nov/22/vanuatu-says-it-may-sue-fossil-fuel-companies-and-other-countries-over-climate -change $>$ accessed 15 November 2020 .

6 'Suva Declaration on Climate Change', PIDF Third Annual Summit, 2-4 September 2015, <http://www.piango.org/wp-content/uploads/2016/o6/PACIFIC-ISLAND-DEVELOPMEN T-FORUM-SUVA-DECLARATION-ON-CLIMATE-CHANGE.v2.pdf $>$ accessed 15 November 2020 .

7 Anote Tong, “Charting Its Own Course”: A Paradigm Shift in Pacific Diplomacy' in Greg Fry and Sandra Tarte (eds), The New Pacific Diplomacy (2015) p. 21.

8 Report on the Structured Expert Dialogue (SED) on the 2013-2015 Review, UN Doc FCCC/ SB/2015/INF.1 (4 May 2015), 18. The SED, established during COP18, formed part of the 2013-2015 review established by the COP during COP16. The SED Report is the outcome of a face-to-face dialogue between over 70 experts and state parties of the Subsidiary Body for Scientific and Technological Advice (sBSTA) and Subsidiary Body for Implementation (SBI) (subsidiary bodies of the COP).

9 'Suva Declaration on Climate Change' (n 6), paras 5 and 9. 
differentiated responsibilities and respective capabilities. ${ }^{10}$ The Declaration also called:

a) for the Agreement to be 'legally binding';

b) for the Agreement to 'establish explicit provisions that ensure the strongest possible efforts will be made to achieve and continuously enhance national and global mitigation action, including review of mitigation targets every 5 years, with opportunities to recommit to stronger action as informed by science';

c) 'for loss and damage to be anchored as a standalone element';

d) for 'increased support for adaptation measures', with provision for such measures to be $100 \%$ grant financed for Pacific Small Island Developing States (SIDS); and

e) 'capacity building on formal and non-formal education, knowledge management, with a particular emphasis on national languages and communication of climate change.'11

In many respects, the PICs were successful in negotiating a text which met these demands. ${ }^{12}$ Developments since 2015 however highlight that those hardfought gains have yet to yield the results that PICs had hoped for. As noted by the Representative of the Federated States of Micronesia at the opening of the High-Level Segment at $\mathrm{COP}_{24}$ :

Our reaching a global agreement in Paris encouraged us. It added hope to our positive efforts under the United Nations Framework Convention on Climate Change (UNFCCC) and built up our belief that global cooperation is possible and that the global devastation we are warned about almost daily from our scientists can be avoided. But now I ask you, do we here at this Conference have the collective resolve to make that Agreement real - to turn it into action? ${ }^{13}$

The following two sections review how the negotiations have evolved in relation to two key areas of interest to PICs and whether the goals of the Paris Agreement are being met with the necessary 'collective resolve'.

\footnotetext{
10 'Suva Declaration on Climate Change' (n 6), para 14.

11 'Suva Declaration on Climate Change' (n 6), para 19.

12 Ian Fry, "The Paris Agreement: An Insider's Perspective. The Role of Small Island Developing States", 46 Environmental Policy and Law (2016) pp. 105-106.

13 Statement for the Hon Sihna N Lawrence Minister of Finance \& Administration Federated States of Micronesia (Katowice, 11 December 2018) <https://unfccc.int/sites/default/files/ resource/MICRONESIA_cop24cmp14cma1-3.pdf > accessed 15 November 2020.
} 


\section{Mitigation and the Ratcheting Mechanism: The Talanoa Dialogue}

The Paris Agreement aims to hold 'the increase in the global average temperature to well below $2^{\circ} \mathrm{C}$ above pre-industrial levels and pursuing efforts to limit the temperature increase to $1.5^{\circ} \mathrm{C}$ above pre-industrial levels. ${ }^{14}$ While the inclusion of the $1.5^{\circ} \mathrm{C}$ target was welcomed by PICs, the aspirational nature of the target was a disappointment. ${ }^{15}$ The subsequent 2018 Intergovernmental Panel on Climate Change (IPCC) Special Report confirmed the importance of keeping the increase in global warming to below the limit of $1.5^{\circ} \mathrm{C}$, and indicated that urgent and unprecedented changes are needed to reach the target. However, these changes are currently not being made, and the window of opportunity for limiting warming to $1.5^{\circ} \mathrm{C}$ is rapidly closing.

Unlike the Kyoto Protocol which set internationally binding emissions targets, ${ }^{16}$ the Paris Agreement leaves it to state-parties to nationally determine their mitigation commitment, provided it reflects their 'highest possible ambition' in light of different national circumstances. ${ }^{17}$ Each state's set of commitments under the Agreement is therefore referred to as its nationally determined contribution (NDC). States must submit an NDC, and update it thereafter every five years. ${ }^{18}$ Setting the regime's 'direction of travel, ${ }^{19}$ each update must represent 'a progression' on a states' current NDC. ${ }^{20}$ While contributions are not legally binding, states must take domestic action 'with the aim of achieving' the objectives of their NDC. ${ }^{21}$ To encourage states to adopt ambitious mitigation commitments, the Agreement contains a range of binding procedural and transparency obligations. For instance, states must provide information regarding their NDC and progress as part of an 'enhanced transparency framework.'22 This information feeds into a five-yearly global stocktake 'to assess the collective progress' towards achieving the long-term temperature goal, ${ }^{23}$ which in turn informs parties efforts in 'updating and enhancing' their

\footnotetext{
14 Paris Agreement, art 2(1)(a).

15 Fry (n 12) pp. 105-106.

16 Kyoto Protocol to the United Nations Framework Convention on Climate Change, adopted 11 December 1997, entered into force 16 February 2005, UN Doc FCCC/CP/L7/ Add1 (10 December 1997).

17 Paris Agreement, art 4(3).

18 ibid, art 4(2) and (9).

19 MJ Mace, "Mitigation Commitments Under the Paris Agreement and the Way Forward", 6 Climate Law (2016) p. 39.

20 Paris Agreement, art 4(3). See also art 3.

21 ibid, art 4(2).

22 ibid, art 13. Also, art 4(8).

23 ibid, art 14(1).
} 
NDCs. ${ }^{24}$ These provisions together form what is referred to as the 'ratchet' or 'ambition' mechanism in the Paris Agreement. In the absence of binding mitigation reduction targets, the success of the Agreement largely depends on the effectiveness of this mechanism.

The Talanoa Dialogue, which was convened to catalyse state action on mitigation pre-2020, was seen as 'a rehearsal for the Paris Agreement's "ambition mechanism". ${ }^{25}$ Following an indication in the 2015 Synthesis Report that the aggregate effect of parties' INDCs was insufficient to meet the long-term temperature goal in the Agreement, ${ }^{26}$ parties agreed to convene a 'facilitative dialogue' 27 - later renamed the Talanoa Dialogue under the Fijian presidency of the COP23. Talanoa is a traditional approach used in Fiji and the Pacific to engage in an inclusive, participatory and transparent dialogue. ${ }^{28}$ Towards building empathy and trust, the Dialogue was to be 'constructive, facilitative and solutions oriented', with the aim of informing decision-making and moving the global climate agenda forward. ${ }^{29}$ Three questions were to be addressed: where are we; where do we want to go; and how do we get there?

Consistent with the inclusive nature of Talanoa, the Dialogue welcomed a broad range of inputs from parties and non-parties alike. ${ }^{30}$ A key input to the Dialogue was the IPCC Special Report. This report highlighted that human activities have already caused around $1^{\circ} \mathrm{C}$ of global warming, ${ }^{31}$ and

24 ibid, art 14(3).

25 Feja Lesniewska and Linda Siegele, "The Talanoa Dialogue: A Crucible to Spur Ambitious Global Climate Action to Stay Within the ${ }_{15}$ C Limit", 12 Carbon \& Carbon Law Review (2018) p. 42.

26 See UNFCCC Secretariat, 'Synthesis report on the aggregate effect of the intended nationally determined contributions', UN Doc FCCC/CP/2015/7 (30 October 2015), and the updated version: 'Aggregate effect of the intended nationally determined contributions: an update', UN Doc FCCC/CP/2016/2 (2 May 2016).

27 Decision 1/CP.21, UN Doc FCCC/CP/2015/10/Add.1 (29 January 2016), para 20. See also Decision 1/CP.22, UN Doc FCCC/CP/2016/10/Add.1 (31 January 2017), para 16. During $\mathrm{COP}_{23}$, the presidencies of $\mathrm{COP}_{22}$ and 23 presented the design of the 2018 facilitative dialogue, to be known as the Talanoa Dialogue. See 'Talanoa Dialogue: Approach' (2017) Decision 1/CP.23, UN Doc FCCC/CP/2017/L.13 (18 November 2017), annex II. See also paras 10-11 of the Decision.

28 ibid 7. A similar community-inspired process was employed by the South African presidency of the COP in 2011 with the 'indaba' process. See Lesniewska and Siegele (n 25) 43.

29 'Talanoa Dialogue: Approach' (n 27) 7.

$30 \quad$ UNFCCC, 'Inputs to the Talanoa Dialogue: Where are we?' $<$ https://unfccc.int/process-andmeetings/the-paris-agreement/the-paris-agreement/2018-talanoa-dialogue-platform/ inputs-to-the-talanoa-dialogue-where-are-we\#eq-2> accessed 15 November 2020. During the preparatory phase, a total of 473 inputs were received, the vast majority of which were from non-parties.

$31 \quad$ IPCC, 'Special Report: Global Warming of $1.5^{\circ} \mathrm{C}$. Summary for Policymakers' (2018) 6 <http://www.ipcc.ch/pdf/special-reports/sr15/sr15_spm_final.pdf> accessed 1 June 2019. 
that climate-related risks are higher for global warming of $2^{\circ} \mathrm{C}$ than $1.5^{\circ} \mathrm{C} .{ }^{32}$ Critically, it made clear that, at the current rate of warming, global warming is likely to reach $1.5^{\circ} \mathrm{C}$ between 2030 and $205^{\prime},{ }^{\prime 3}$ and that in order to keep global warming below $1.5^{\circ} \mathrm{C}$, emissions must decline by about $45 \%$ from 2010 levels by 2030, reaching net zero around 2050. ${ }^{34}$ The Report thus confirmed the position of PICs that states must urgently step-up their efforts to reduce Green House Gas (GHG) emissions.

Despite the alarming nature of the IPCC Special Report, the Dialogue failed to produce a strong outcome. Prior to $\mathrm{COP} 24$, SIDS made clear their position that a COP decision was a 'crucial component' of the Dialogue for the purpose of providing 'concrete guidance/next steps through to 2020 for Parties in preparing or updating NDCs and enhancing ambition'. ${ }^{35}$ Even so, the primary output of the Dialogue was a political declaration issued by the Presidents of $\mathrm{COP}_{23}$ and COP24: the 'Talanoa Call for Action', which simply called on governments to 'continue to strengthen national policies and regulatory and institutional frameworks that deliver action and support until 2020 and beyond. ${ }^{36}$

Such action and support pre-2020 did not, however, come to fruition. In the lead-up to $\mathrm{COP}_{25}$, the PIDF released the Nadi Bay Declaration on the Climate Change Crisis in the Pacific, expressing 'deep concern' about the lack of comprehension and action on the part of developed countries 'regarding the impending grave consequences that the current and ongoing Climate Crisis poses' for PICs. ${ }^{37}$ This was followed by the Kainaki II Declaration for Urgent

$32 \quad$ ibid 7 .

33 ibid 6.

34 ibid 14.

35 Submission of AOsis, 'The Talanoa Dialogue (TD) - The political phase and potential outputs' <www4.unfccc.int/sites/SubmissionsStaging/Documents/201809191827---2018091 91808---Final\%2oAOSIS\%2oTalanoa\%2oSubmission.pdf> accessed 15 November 2020. See also Statement during the High-Level Segment at COP24, Melchior Mataki, Ministry of Environment, Climate Change, Disaster Management \& Meteorology, Solomon Islands, (Katowice, 12 December 2019) <https://unfcc.int/sites/default/files/resource/ SOLOMONISLANDS_cop24cmp14cma1-3.pdf> accessed 15 November 2020; Submission of AILAC-CARICOM-EIG, "The Talanoa Dialogue (TD) - The political phase and potential outcomes' <https://unfccc.int/sites/default/files/resource/AILAC-CARICOM-EIG\%2oThe \%20Talanoa\%2oDialogue\%2oOutcomes\%2oConceptual\%2oNote\%2ov9_draft\%2O FINAL.pdf> accessed 15 November 2020.

36 'Talanoa Call for Action', Presidents of COP23 and COP24, 12 December 2018, <https:// unfccc.int/sites/default/files/resource/Talanoa\%2oCall\%2ofor\%20Action.pdf> accessed 15 November 2020. The relevant cop decision was similarly weak. See Decision 1/CP.24, UN Doc FCCC/CP/2018/10/Add.1 (19 March 2019), para 37.

37 'Nadi Bay Declaration on the Climate Change Crisis in the Pacific', PIDF (30 July 2019) <https://cop23.com.fj/nadi-bay-declaration-on-the-climate-change-crisis-in-the -pacific/> accessed ${ }_{15}$ November 2020. 
Climate Action Now, adopted by the PIF..$^{38}$ In addition to reiterating the urgent need for more ambitious climate action by states, the Declaration signalled the proposal to seek a resolution from the UN General Assembly to request an Advisory Opinion from the International Court of Justice 'on the obligations of States under international law to protect the rights of present and future generations against the adverse effects of climate change' - indicating the frustration of PICS with the UNFCCC process. The final outcome of $\mathrm{COP}_{25} 5$ yet failed to deliver: states acknowledged in the final decision 'the urgent need to address the significant gap' between states' mitigation commitments and the temperature goal, but no concrete action towards achieving this was agreed. ${ }^{39}$

From the perspective of PICs (and other climate vulnerable countries), 2020 was therefore supposed to be 'crunch-time', 40 representing the commencement of the formal ratchet mechanism under the Paris Agreement. Under the Agreement, parties were required to take further action in respect of their NDCs in 2020. ${ }^{41}$ This will feed into the first global stocktake in $2023,{ }^{42}$ which will in turn inform the next round of NDC updates in $2025 .{ }^{43}$ Given that states' current national climate commitments are blatantly inadequate to achieve the climate goals of the Paris Agreement,' ${ }^{44}$ it is critical that NDCs are updated and enhanced if the Agreement's goals are to be met. As noted by a report of the UNFCCC and UNDP in 2019: '[d] eveloping nations are currently the frontrunners in preparations to revise plans for combatting the climate crisis over the next decade by 2020.45 PICs feature prominently among the frontrunners: the Marshall Islands was the first country in the world to submit a more

38 'Kainaki II Declaration for Urgent Climate Action Now', 5oth Pacific Islands Forum, Forum Communiqué (13-16 August 2019) <https://www.forumsec.org/wp-content/ uploads/2019/08/5oth-Pacific-Islands-Forum-Communique.pdf $>$ accessed 15 November 2020.

39 Decision 1/CMA.2 (Madrid 2019), UN Doc FCCC/PA/CMA/2019/6/Add.1 (16 March 2020).

40 Permanent Mission of Tuvalu to the United Nations, 'Pacific Islands Forum Chair Statement on the Outcome of COP 25 in Madrid' (21 December 2019) <https://www .un.int/tuvalu/statements_speeches/pacific-islands-forum-chair-statement-outcome -cop-25-madrid $>$ accessed 15 November 2020.

41 Decision 1/CP.21, UN Doc FCCC/CP/2015/10/Add.1 (29 January 2016), paras 23 and 24. Countries with a 2025 mitigation target must communicate a new NDC, while those countries with a 2030 target must 'communicate or update by 2020 these contributions'.

42 Paris Agreement, art 14(2).

43 ibid, art 14(3).

44 United Nations Environment Programme, 'The Emissions Gap Report 2019' (2019) 25 $<$ https://www.unenvironment.org/resources/emissions-gap-report-2019> accessed 19 January 2020.

45 UNFCCC and UNDP, 'The Heat is On: Taking Stock of Global Climate Ambition' (September 2019) <https://unfccc.int/sites/default/files/resource/NDC\%2oOutlook.pdf> accessed 15 November 2020 . 
ambitious second NDC in $2018,{ }^{46}$ and several PICs have already indicated their intention to submit more ambitious NDCs. ${ }^{47}$ Developed countries, meanwhile, are lagging behind - a situation compounded by the global pandemic and the consequent delay of $\mathrm{COP}_{2} 6$. Time is, however, running out. Without 'quick wins', 'the $1.5^{\circ} \mathrm{C}$ goal ... will slip out of reach' ${ }^{48}$ - with catastrophic consequences for PICs.

For 24 years, parties have been gathering at these cops to negotiate and discuss climate change. In that same period, five islands in my country have disappeared, communities have been internally displaced and we are in constant mode of recovery from extreme weather events. As the IPCC $1.5^{\circ} \mathrm{C}$ [Special Report] highlights, global efforts are off-track at best from the objectives of the Convention and the Paris Agreement. ${ }^{49}$

PICs are already experiencing loss and damage resulting from climate change from both extreme weather events and slow onset climatic processes. ${ }^{50}$ In 2015, Cyclone Pam - the largest ever recorded tropical cyclone in the South Pacific at the time - struck the South Pacific. ${ }^{51}$ Vanuatu was the worst hit: in addition to loss of life, physical injuries and damage to ecosystems, the estimated cost of the financially assessable damage was US $\$ 450$ million, or

46 Fatima-Zahra Taibi et al, 'Pocket Guide to NDCs under the UNFCCC: 2020 Edition' (2nd edition, 2020), 5 o.

47 See Climate Watch, 2020 NDC Tracker, <https://www.climatewatchdata.org/202o-ndc -tracker> accessed 6 November 202o. Palau, Micronesia, Nauru, Tuvalu, Fiji and Solomon Islands have indicated their intention to update their 2020 NDCs.

48 United Nations Environment Programme, 'The Emissions Gap Report 2019' (2019) 25 <https://www.unenvironment.org/resources/emissions-gap-report-2019> accessed 19 January 2020. Foreword by Inger Anderson, XIII.

49 Melchior Mataki, Ministry of Environment, Climate Change, Disaster Management \& Meteorology, Solomon Islands, Statement during the High-Level Segment at COP24 (Katowice, 12 December 2019) <https://unfccc.int/sites/default/files/resource/SOLOM ONISLANDS_cop24cmp14cma1-3.pdf > accessed 15 November 2020.

50 Decision 1/CP.16, UN Doc FCCC/CP/2010/7/Add.1 (15 March 2011), para 25.

51 Cyclone Winston, which hit Fiji in 2016, was stronger still. SP Sopko and RJ Falvey, 'Annual Tropical Cyclone Report 2015' (Joint Typhoon Warning Center 2015) 84; JM Bushnell and RJ Falvey, 'Annual Tropical Cyclone Report 2016' (Joint Typhoon Warning Center 2016) 68. See Pacific Beat, 'Cyclone Winston: Damage Bill Reaches \$65o Million, Fiji Government Says' ABC News (25 February 2016) <https://www.abc.net.au/news/2016-o2-26/cyclone -winston-damage-bill-reaches-650-million-dollars/7201846> accessed 15 November 2020. 
$64 \%$ of Vanuatu's GDP. ${ }^{52}$ A year prior - faced with slow onset events such as coastal erosion, sea-level rise and sea-water intrusion - the Government of Kiribati purchased land in 2014 on Vanua Levu, Fiji's second largest island. ${ }^{53}$ The purchase, which is part of its 'migration with dignity' policy, was intended to help secure the country's food security. Human migration from Kiribati to Fiji may also be necessary in the long-term. ${ }^{54}$ Highlighting the 'irreversible loss and damage caused by climate change', the Suva Declaration therefore called for 'loss and damage to be anchored as a standalone element [in the Paris Agreement] that is separate and distinct from adaptation. ${ }^{55}$

PICs have consistently campaigned for loss and damage to be included within the climate treaty regime since its establishment. ${ }^{56}$ During the negotiations of the UNFCCC, Vanuatu on behalf of AOsis called for the assistance of the international community in the form of an international insurance pool modelled on the oil pollution and nuclear damage conventions. ${ }^{57}$ Several years later following the inclusion of loss and damage in the Bali Action Plan (2007), AOsis submitted a proposal for a Multi-Window Mechanism to Address Loss

52 Global Facility for Disaster Reduction and Recovery (GFDRR), Infographic Cyclone Pam, $<$ www.gfdrr.org/sites/default/files/publication/infographic-cyclone-pam.pdf > accessed 15 November 2020. See also Global Facility for Disaster Reduction and Recovery (GFDRR), 'Vanuatu', <www.gfdrr.org/en/vanuatu> accessed ${ }_{5}$ November 2020.

53 Laurence Caramel, 'Besieged by the Rising Tides of Climate Change, Kiribati Buys Land in Fiji' The Guardian (1 July 2014) <https://www.theguardian.com/environment/2014/jul/o1/ kiribati-climate-change-fiji-vanua-levu> accessed 15 November 2020.

54 Press Release, Government of Kiribati, 'Kiribati Buys a Piece of Fiji | Climate Change' (30 May 2014) <http://www.climate.gov.ki/2014/o5/30/kiribati-buys-a-piece-of-fiji/> accessed 15 November 2020. Then President of Fiji Ratu Epeli Nailatikau made assurances 'that the people of Kiribati will have a home if their country is submerged by the rising sea level as a result of climate change'.

55 'Suva Declaration on Climate Change' (n 6) para 19(d).

56 John W Ashe, Robert Van Lierop and Anilla Cherian, 'The Role of the Alliance of Small Island States (AOSIS) in the Negotiation of the United Nations Framework Convention on Climate Change (UNFCCC)' 23 Natural Resources Forum (1999) pp. 217-218, see also 215. Erin Roberts and Saleemul Huq, 'Coming Full Circle: The History of Loss and Damage under the UNFCCC' 8 International Journal of Global Warming (2015) p. 141.

57 Vanuatu, Draft Annex Relating to Article 23 (Insurance) for Inclusion in the Revised Single Text on Elements Relating to Mechanisms (UN Doc A/AC.237/WG.II/Misc.13), Submitted by the Co-Chairmen of Working Group II, UN Doc A/AC.237/WG.II/ CRP.8 (17 December 1991) 7; reprinted in Report of the Intergovernmental Negotiating Committee for a Framework Convention on Climate Change on the work of its fourth session, held at Geneva from 9 to 20 December 1991, UN Doc A/AC.237/15 (29 January 1992) 126-127. 
and Damage from Climate Change Impacts. ${ }^{58}$ These efforts eventually led to the establishment of the Warsaw International Mechanism for Loss and Damage associated with Climate Change Impacts (WIM) in 2013, which was tasked with 'promoting the implementation of approaches to address loss and damage associated with the adverse effects of climate change ... in a comprehensive, integrated and coherent manner'.59 The reference to the WIM in the Paris Agreement established it as a permanent feature of the climate treaty regime. ${ }^{60}$

Throughout negotiations, loss and damage has remained an 'amorphous concept to which policy actors attached different meanings'. ${ }^{61}$ For developing countries, loss and damage refers to those effects that exceed the limits of adaptation, ${ }^{62}$ while developed countries understand the concept to be much narrower. The result is a dichotomous framing: one which encompasses compensation and liability vis-à-vis one which is limited to risk and insurance. ${ }^{63}$ The inclusion of a dedicated article on loss and damage in the Paris Agreement went some way to resolving this ambiguity. As a standalone provision, loss and damage was formally established as a separate element of the climate treaty regime, ultimately meeting the demand of PICs under the Suva Declaration. Article 8 of the Paris Agreement recognises 'the importance of averting, minimising, and addressing loss and damage associated with the adverse effects of

$5^{8}$ 'Multi-Window Mechanism to Address Loss and Damage from Climate Change Impacts: Proposal to the AWG-LCA' (Alliance of Small Island States (Aosis)) <http:// unfccc.int/files/kyoto_protocol/application/pdf/aosisinsuranceo612o8.pdf>, accessed 15 November 2020.

59 Decision 2/CP.19, UN Doc FCCC/CP/2013/10/Add.1 (31 January 2014), para 5.

6o Paris Agreement, art 8(3).

61 Lisa Vanhala and Cecilie Hestbaek, "Framing Climate Change Loss and Damage in UNFCCC Negotiations”, 16 Global Environmental Politics (2016) p. 112. See also Emily Boyd, Rachel James and Richard Jones, 'Typologies of Loss and Damage and Associated Actions' (2016) Policy Brief Revised from a Draft Prepared for the April 2016 Meeting of the WIM Executive Committee, University of Reading, Environmental Change Institute at Oxford University, and Met Office Hadley Centre <https://www.eci.ox.ac.uk/publications/policybrief-pdf/16o6o8_Typologies_ExCom3Update_Final.pdf > accessed 15 November 2020.

62 Karen E McNamara and Guy Jackson, "Loss and Damage: A Review of the Literature and Directions for Future Research", 10 Wiley Interdisciplinary Reviews: Climate Change (2019). According to the analysis of McNamara and Jackson, researchers primarily conceptualise loss and damage as 'limits to adaptation'. This view is generally shared by PIC leaders, who have consistently emphasised the need to distinguish loss and damage from adaptation. Decision 2/CP.19, which established the WIM, at least incorporates this understanding. It notes in the preamble 'that loss and damage associated with the adverse effects of climate change includes, and in some cases involves more than, that which can be reduced by adaptation'.

63 Vanhala and Hestbaek (n 61). 
climate change' ${ }^{64}$ Without defining loss and damage, the Agreement indicates that it includes slow onset events; events that 'may involve irreversible and permanent loss and damage'; non-economic losses; and resilience building. ${ }^{65}$ In these areas, parties 'should enhance understanding, action and support ... on a cooperative and facilitative basis'.66

The inclusion of an article on loss and damage, however, entailed compromises on the part of vulnerable states. The COP decision accompanying the Agreement states that parties 'agree that Article 8 of the Agreement does not involve or provide a basis for any liability and compensation', ${ }^{67}$ Reflecting developed countries' key concern in respect of loss and damage, this language seeks to exclude compensation for damage caused by the high GHG emissions of mainly developed countries from the mandate of the wIM. The legal effect of this statement on the rights of PICs is limited. ${ }^{68}$ Nevertheless, it indicates the significant opposition PICs and other vulnerable countries have faced in ensuring that loss and damage is appropriately incorporated into the climate treaty regime. This opposition continues to hamper further progress. ${ }^{69}$

During COP24, states negotiated the 'rulebook' for the Paris Agreement towards operationalising the Agreement. ${ }^{70}$ Despite a lack of reference to loss and damage outside of Article 8, negotiators from vulnerable states were

64 Paris Agreement, art 8(1).

65 ibid, art 8(4).

66 ibid art $8(3)$.

67 Decision 1/CP.21, UN Doc FCCC/CP/2015/10/Add.1 (29 January 2016), para 52.

68 MJ Mace and Roda Verheyen, 'Loss, Damage and Responsibility after COP21: All Options Open for the Paris Agreement' (2016) 25 Review of European, Comparative \& International Environmental Law 197. See also M Wewerinke-Singh and C Doebbler, 'The Paris Agreement: Some Critical Reflections on Process and Substance' 39 Unsw Law Journal 1486, 1504-1506; Maxine Burkett, 'Reading Between the Red Lines: Loss and Damage and the Paris Outcome' (2016) 6 Climate Law 118. For the avoidance of doubt, several PICs made declarations when ratifying the Paris Agreement that it in no way constitutes a renunciation of any rights under international law concerning state responsibility for the adverse effects of climate change. The Cook Islands, Marshall Islands, Micronesia, Nauru, Niue, Philippines, Solomon Islands, Tuvalu and Vanuatu made such a declaration. See UN Treaty Collection, Depository <https://treaties.un.org/ Pages/ViewDetails.aspx?src=TREATY\&mtdsg_no=XXVII-7-d\&chapter=27\&clang=_en $>$ accessed 15 November 2020.

69 As explained by Vanhala and Hestbaek, 'developed states have historically eschewed policy initiatives that place the responsibility for addressing the impacts of climate change on them', employing 'a variety of tactics to avoid discussion and to scupper policy initiatives on the issue.' Vanhala and Hestbaek (n 61) pp. 111-112.

70 See UN Doc FCCC/PA/CMA/2018/3/Add.1 (19 March 2019) and UN Doc FCCC/PA/ CMA/2018/3/Add.2 (19 March 2019). The Mandate for the Ad Hoc Working Group on the Paris Agreement stems from Decision 1/CP.21, para 26. 
successful in securing key references to loss and damage in the rulebook regarding the 'enhanced transparency framework' (Article 13), ${ }^{71}$ and the global stocktake (Article 14). ${ }^{72}$ These references were a positive development for PICs and mean that states can report on loss and damage as part of the transparency framework under the Paris Agreement, which can in turn feed into the global stocktake process. ${ }^{73}$

These wins, obscure a lack of tangible progress in terms of loss and damage more generally. As noted by Pekkarinen et al: 'Though the creation of the WIM has often been described as a political victory for developing countries, its operation to date reflects the low priority that loss and damage has been given within the climate regime. ${ }^{74}$ The wIM has so far primarily adopted a bureaucratic approach in exercising its mandate, focusing on the collection and dissemination of information. This 'excessive focus on "technocratic" policy solutions'75 has been identified as contributing to the 'depoliticizing of many of the factors that underscore arguments surrounding [loss and damage], ${ }^{76}$ notably historical responsibility and differentiation.

The review of the WIM at $\mathrm{COP}_{25}$ (2019) was seen as an important opportunity to unlock progress going forward. ${ }^{77} \mathrm{~A}$ key input to the review was a Technical Paper elaborating the sources of financial support for addressing loss and damage as well as modalities for accessing such support, ${ }^{78}$ which was informed by the 2018 Suva Expert Dialogue. ${ }^{79}$ Bringing together over 200 experts, the Dialogue was tasked with exploring 'a wide range of information, inputs and views' on ways to facilitate the mobilization of expertise and support

71 UN Doc FCCC/PA/CMA/2018/3/Add.2 (19 March 2019), 35 .

72 UN Doc FCCC/PA/CMA/2018/3/Add.2 (19 March 2019), 57. See also 54.

73 Olivia Serdeczny, Dawn Pierre-Nathoniel and Linda Siegele, 'Progress on Loss and Damage in Katowice' (Climate Analytics, 17 December 2018) <https://climateanalytics. $\mathrm{org} / \mathrm{blog} / 2018 /$ progress-on-loss-and-damage-in-katowice/> accessed 15 November $202 \mathrm{O}$.

74 Veera Pekkarinen, Patrick Toussaint and Harro van Asselt, 'Loss and Damage after Paris: Moving Beyond Rhetoric' (2019) 13 Carbon \& Climate Change Review 31, 38.

75 Julia Kreienkamp and Lisa Vanhala, 'Climate Change Loss and Damage' (2017) Policy Brief: Global Governance Institute 13 <https://www.ucl.ac.uk/global-governance/news/2017/ mar/climate-change-loss-and-damage > accessed 15 November 2020.

$76 \quad$ McNamara and Jackson (n 62) p. 11.

77 See Decision 4/CP.22, UN Doc FCCC/CP/2016/10/Add.1 (31 January 2017).

78 ibid, para 2(f). The Technical Report is UN Doc FCCC/TP/2019/1 (14 June 2019).

79 'Report of the Suva Expert Dialogue: Loss and Damage Associated with Climate Change Impacts' (2018) <https://unfccc.int/sites/default/files/resource/SUVA\%2oReport_ver _13_Nov.pdf> 15 November 2020. See also: Decision 5/CP.23, Warsaw International Mechanism for Loss and Damage associated with Climate Change Impacts, UN Doc FCCC/CP/2017/11/Add.1 (8 February 2018), para 9. 
for averting loss and damage. ${ }^{80}$ The submission of Vanuatu in advance of the Dialogue highlights the need for the WIM to focus more efforts on achieving its third function to enhance action and support. It called for the establishment of a stand-alone finance arm of the WIM; an agreed minimum target for loss and damage financial flows (per year by 2020 and 2030); sources of loss and damage finance (including public finance and new innovative sources); a comprehensive set of agreed modalities for channelling loss and damage finance, including direct access; and a firm proposal as to how to anchor loss and damage within the overarching framework of the UNFCCC financial mechanism, including formal links to the Green Climate Fund (GCF) and the Adaptation Fund. ${ }^{81}$

The COP decision on the 2019 Review pointed to progress in some respects, but failed to deliver in others. ${ }^{82}$ The decision recognises 'the urgency of enhancing the mobilisation of action and support, including finance, technology and capacity-building, for developing countries that are particularly vulnerable' to loss and damage, ${ }^{83}$ and urges 'the scaling-up of action and support' ${ }^{\prime 84}$ including by non-state actors. ${ }^{85}$ However, no provision is made to ensure that such additional action and support is actually provided, nor is any reference made to developed countries' specific obligation to provide such support. Rather, the decision 'acknowledges the wide variety of sources of finance' relevant to supporting approaches to avert or minimise loss and damage, and 'invites' parties to make use of the existing available support, both under and outside the UNFCCC and Paris Agreement. ${ }^{86}$ To facilitate this, the decision calls for greater collaboration between the Executive Committee and the Standing Committee on Finance and the Green Climate Fund. ${ }^{87}$ The decision also establishes the

8o $\quad$ See ibid 3 and 5 .

81 Republic of Vanuatu, 'Vanuatu Submission Action and Support Finance for Loss \& Damage' (2018) Submission to the Executive Committee of the Warsaw International Mechanism for Loss and Damage of the UNFCCC $2<$ https:/unfccc.int/sites/default/files/ resource/Vanuatu\%2oSubmission\%20Action\%2oand\%2oSupport\%2oFINANCE\%2O for\%2oLoss\%2o\&\%2oDamage.pdf> accessed 15 November 2020, pp. 2-3.

82 Decision 2/CMA.2, UN Doc FCCC/PA/CMA/2019/6/Add.1 (16 March 2020). See also Decision $2 /$ CP.25.

83 ibid, para 31.

84 ibid, para 32.

85 ibid, para 33 .

86 ibid, paras 34 and 35 .

87 See also Decision 5/CMA.2 para 13 (regarding the Standing Committee on Finance) and Decision 6/CMA.2 para 8 (regarding the Green Climate Fund). See also Decision 1/CP.25 para 13 which 'Calls on international entities, including financial institutions, to continue supporting the development and implementation of measures to avert, minimize and address the adverse impacts of climate change'. 
Santiago Network as part of the WIM, to 'catalyse the technical assistance' required by the most vulnerable countries ${ }^{88}$ and encourages parties to 'establish a loss and damage contact point'. ${ }^{89}$

PICS are still, however, faced with the pressing question: how to finance the loss and damage that they are already experiencing. As noted by Aosis in its Closing Statement at $\mathrm{COP}_{25}$, " $[1]$ oss and damage is an existential issue for Aosis member states. Several islands in the Pacific have already been inundated, lives have been lost. ${ }^{90}$ Identifying new and additional sources of finance therefore remains critical for PICs. Insurance-based approaches are often identified as an option. However, in addition to being of limited assistance in respect of slow onset events, insurance is a use rather than a source of finance. ${ }^{91}$ Going forward, it is therefore necessary to consider how a climate risk insurance scheme will be financed to ensure it is an accessible option for vulnerable communities. An insurance pool which countries contribute to on the basis of the principle of common but differentiated responsibilities is an option. ${ }^{92}$ To date, however, states have been reluctant to agree to such a proposal. Other finance tools might also be directed at the private sector. ${ }^{93}$ In this vein, the proposal of Pekkarinen et al 'to tie an insurance-based approach to some form of strict civil liability' could apply in respect of major polluting or fossil fuel companies on the basis of the polluter-pays principle. ${ }^{94}$ An alternative would be a 'climate damages tax' that would see royalties paid to states by fossil fuel companies channeled into a loss and damage facility under the GCF,

88 Decision 2/CMA.2 (n 82), para 43.

89 ibid, para 13.

90 Aosos, 'COP25 - AOSIS Closing Statement', Madrid, Spain (12 December 2015) <https:// www.aosis.org/2019/12/15/cop-25-aosis-closing-statement/> accessed 15 November 2020.

91 See Climate Action Network, 'CAN Loss and Damage Submission' (2018) Submission on the Scope of the Technical Paper Exploring Sources of Support for Loss and Damage and Modalities for Accessing Support 5 <https://unfccc.int/sites/default/files/ resource/CAN\%2oLoss\%2oand\%2oDamage\%2oSubmission_\%20022018.pdf> accessed 15 November 2020.

92 McNamara and Jackson (n 62) p. 1o. Pekkarinen, Toussaint and van Asselt (n 74) p. 46.

93 For instance, Roberts et al identify several mechanisms that could be directed at the private sector, including a financial transaction tax, an international airline passenger levy, a solidarity levy, a bunker fuels levy, a fossil fuel majors carbon levy, and global carbon tax. J Timmons Roberts and others, 'How Will We Pay for Loss and Damage?' (2017) 2o Ethics, Policy \& Environment 208. See also Julie-Anne Richards and Keely Boom, 'Big Oil, Coal and Gas Producers: Paying for Their Climate Damage' (Heinrich Boll Stiftung 2014) Vol 39. Pekkarinen, Toussaint and van Asselt (n 74) p. 46. 
as proposed by Vanuatu. ${ }^{95}$ The exclusion of liability and compensation from the scope of the WIM at present indicates the political, if not legal, obstacles to establishing such a mechanism within the current climate treaty regime.

\section{$5 \quad$ Conclusion}

PICs have punched above their weight in influencing the international climate treaty regime. They managed - in coalition with other vulnerable countries to secure the inclusion of the $1.5^{\circ} \mathrm{C}$ long-term temperature goal in the Paris Agreement (albeit in a diluted form), along with a separate article on loss and damage. More than five years down the track, however, the climate treaty regime is failing to deliver the reductions in global GHG emissions that are needed to mitigate dangerous climate change, and the support needed to help PICs deal with the resulting loss and damage. PIC leaders are therefore rightly looking outside the climate treaty regime for other legal tools and mechanisms that can be put to use to prevent catastrophic climate impacts in the region. This includes the option of state-based international litigation, either by way of a contentious case before an international court or tribunal, or a request for an advisory opinion from the same. Another option is litigation against fossil fuel companies. ${ }^{96}$ While none of these options are free from risks or potential downsides, the continued lack of real progress via the climate treaty regime means that all options appear to be on the table

\footnotetext{
95 Margaretha Wewerinke-Singh and Diana Salili, "Between Negotiations and Litigation: Vanuatu's Perspective on Loss and Damage from Climate Change", 2o(6) Climate Policy (2020) p. 681.

96 ibid.
} 